\title{
Effect of a transplantable insulinoma upon serotonin concentrations in the intestine of the rat
}

\author{
J M CONLON, C J BAILEY, AND P R FLATT \\ From the Clinical Research Group for Gastrointestinal Endocrinology of the Max-Planck-Gesellschaft at the \\ University of Göttingen, Göttingen, FRG, Department of Molecular Sciences, University of Aston in \\ Birmingham, and the Department of Biochemistry, University of Surrey, Guildford, Surrey.
}

SUMMARY Rapid growth of a transplantable insulinoma in rats over a 14 day period results in hyperphagia together with a selective increase in the weight and enteroglucagon (GLI) concentration of the small intestine. Measurement of serotonin concentrations by an HPLC/fluorometric method demonstrated an increase in blood $(91 \% ; \mathrm{p}<0.05)$ and in extracts of colon $(22 \% ; \mathrm{p}<0.05)$ but no change in extracts of the small intestine and caecum. The data support the hypothesis that the rise in enteroglucagon is related directly to the growth of the small intestine and is not a non-specific effect of hyperphagia.

Growth of a transplantable insulinoma ${ }^{1}$ in NEDH (New England Deaconess Hospital) rats results in the development of hyperphagia, hyperinsulinaemia and hypoglycaemia, leading to fatal neuroglycopenic coma by two to three weeks ${ }^{23}$. A previous study ${ }^{4}$ has demonstrated that tumour growth over a 14 day period led to an increase in the weight of the small intestine concomitant with an increase in the concentration of enteroglucagon (GLI). Concentrations of peptides localised exclusively to intestinal nerves were not raised. Small intestinal mucosal hyperplasia occurs in several situations of hyperphagia - for example, lactation, hypothalamic lesions and coldadaptation (reviewed by Barrowman ${ }^{5}$ ) and the involvement of a humoral trophic factor has been postulated. ${ }^{5}$ The physiological role, if any, of enteroglucagon is unknown but it has been proposed that it represents a factor that promotes mucosal growth in the small intestine. ${ }^{67}$ Whilst the rise in enteroglucagon concentration in the intestines of the tumour bearing rats is consistent with this hypothesis, the increase may have been a non-specific effect of hyperphagia arising from stimulation of the mucosa by malabsorbed nutrients. Serotonin, like enteroglucagon, ${ }^{8}$ is located predominantly in the epithelial layer of the intestine with $>99 \%$ localised to mucosal enterochromaffin (EC) cells. ${ }^{910}$ In this study, it is shown that tumour induced hyperphagia does not lead to an increase in serotonin concentration in the small

Address for correspondence: $\mathrm{Dr} \mathrm{J} M$ Conlon, Klinische Arbeitsgruppe der MPG, Goßlerstraße 10d, D-3400 Göttingen, FRG. intestine, providing support for the view that the observed increase in enteroglucagon is selective and related directly to growth of the organ.

\section{Methods}

\section{ANIMALS}

Fragments of insulinoma tissue (approximately $0 \cdot 1 \mathrm{~g}$ ) from a single donor rat were implanted subcutaneously into the subscapular region of 19 week old male, inbred NEDH (New England Deaconess Hospital, Boston MA, USA) rats $(n=13)$ as previously described. ${ }^{2-4}$ Six male rats of the same age and strain served as controls. On day 14 , six tumour bearing rats died and so the experiment was terminated. All surviving animals were killed by cervical dislocation. The stomachs of rats from both groups contained food at the time of death. Tumour tissue, the entire small intestine, colon and caecum were removed, washed with saline and immediately frozen on dry ice. The tissues were weighed and stored at $-70^{\circ} \mathrm{C}$ until time of extraction. A blood sample $(0.5 \mathrm{ml})$ was obtained by cardiac puncture at the time of death.

\section{EXTRACTION OF TISSUES}

Tumour and gastrointestinal tissues were extracted by a modification of procedures optimised for extraction of serotonin from rodent brain. ${ }^{11}$ Frozen tissue $(1 \mathrm{~g})$ was homogenised in $0.4 \mathrm{M}$ perchloric acid $(4 \mathrm{ml})$ containing EDTA $(20 \mathrm{mg})$ and ascorbic acid $(40 \mathrm{mg})$ using an Ultraturrax blender (Janke and Kunkel 
$\mathrm{GmbH}$, Staufen, FRG) after centrifugation $(30000 \mathrm{~g}$ for $20 \mathrm{~min})$, the supernatants were filtered $(0.22 \mu \mathrm{m})$ and stored at $-70^{\circ} \mathrm{C}$. Platelet disruption in the blood sample was accomplished by immediate addition of water $(0.5 \mathrm{ml})$ containing ascorbic acid $(4.5 \mathrm{mg})$ followed by $4 \mathrm{M}$ perchloric acid $(200 \mu \mathrm{l})$. The tubes were vortex mixed for $20 \mathrm{sec}$ and centrifuged (12000 $\mathrm{g}$ for $10 \mathrm{~min}$ ). The supernatants were filtered and stored at $-70^{\circ} \mathrm{C}$ until time of assay.

\section{DETERMINATION OF SEROTONIN AND RELATED METABOLITES}

Measurements were carried out by a modification of a previously described high performance liquid chromatographic method with fluorometric detection. ${ }^{12}$ Sample $(50 \mu \mathrm{l})$ was injected onto a Radial Pak $\mu$ Bondapak $\mathrm{C} 18$ cartridge (Waters Association) eluted under isocratic conditions (flow rate $2.5 \mathrm{ml} /$ $\mathrm{min}$ ) with $0.01 \mathrm{M}$ sodium acetate buffer, $\mathrm{pH} 4.0$ containing $10 \% \mathrm{v} / \mathrm{v}$ methanol. Signals from the fluorimeter (Kontron SFM-23; excitation wavelength $340 \mathrm{~nm}$, emission wavelength $280 \mathrm{~nm}$ ) were quantitated using a Milton Roy CI-10 integrator.

STATISTICAL ANALYSIS

Data were expressed as mean \pm SD and comparisons between groups are made using the Mann-Whitney $U$ test. Confidence limits were set at $\mathrm{p}<0.05$.

\section{Results}

\section{EFFECT OF TUMOUR GROWTH}

Consistent with the observations in a previous study, ${ }^{4}$ the insulinoma bearing rats had become, by 14 days, hyperphagic, markedly hyperinsulinaemic (plasma insulin $29.9 \pm 6.1 \mathrm{ng} / \mathrm{ml}$, control $2.6 \pm 0.4 \mathrm{ng} /$ $\mathrm{ml} ; \mathrm{p}<0.01$ ) and hypoglycaemic (plasma glucose $3.4 \pm 0.6 \mathrm{mmol} / 1$, control $6.7 \pm 0.5 \mathrm{mmol} / \mathrm{l} ; \mathrm{p}<0.01$ ). Hyperphagia in the tumour-bearing rats did not result in a significant increase in final body weight $(375 \pm 70 \mathrm{~g}$, control $358 \pm 30 \mathrm{~g})$. As shown in Table 1 , the weight of the small intestine in the tumour rats was greater $(34 \% ; \mathrm{p}<0.05)$ than in control animals but the weights of the colon and caecum were not significantly different.

Table 1 Effect of tumour growth on tissue weights

\begin{tabular}{lcc}
\hline & $\begin{array}{l}\text { Insulinoma } \\
(n=7)\end{array}$ & $\begin{array}{c}\text { Control } \\
(n=6)\end{array}$ \\
\hline Tumour & $2 \cdot 46 \pm 1.26 \mathrm{~g}$ & \\
Small intestine & $8.6 \pm 1.4^{*}$ & $6.4 \pm 0.7$ \\
Colon & $1.9 \pm 0.3$ & $1.7 \pm 0.3$ \\
Caecum & $1.2 \pm 0.2$ & $1.0 \pm 0.2$ \\
\hline
\end{tabular}

Results are expressed as mean \pm SD. ${ }^{*} p<0.05$.

\section{MEASUREMENT OF SEROTONIN AND RELATED} METABOLITES

Under the conditions of chromatography described, a complete separation of serotonin and its principal precursors and metabolite was achieved. Retention times in a representative run were 5-hydroxytryptophan (4.31 $\mathrm{min})$, serotonin (5.64 $\mathrm{min}$ ), L-tryptophan $(8.16 \mathrm{~min})$ and 5-hydroxyindole acetic acid (14.43 min). Retention times differed by $<10 \%$ between assays. The intra- and intercoefficients of variability for a $100 \mathrm{ng} / \mathrm{ml}$ serotonin standard in this series of experiments were $1.8 \%$ and $5 \cdot 1 \%$.

\section{CONCENTRATION OF SEROTONIN IN TISSUE EXTRACTS}

Extracts of tumour tissue contained serotonin $(2.4 \pm 0.8 \mathrm{nmol} / \mathrm{g}$; range $1.9-3.7 \mathrm{nmol} / \mathrm{g})$, tryptophan $(53 \pm 6 \mathrm{nmol} / \mathrm{g}$; range $47-67 \mathrm{nmol} / \mathrm{g})$ but 5-hydroxytryptophan and 5-hydroxyindole acetic acid were not detected. Concentrations of serotonin and tryptophan in extracts of whole blood from the tumour bearing rats were significantly raised $(\mathrm{p}<0.05)$ relative to controls [serotonin: insulinoma $4.43 \pm 1.23 \mathrm{nmol} / \mathrm{ml}$, control $2 \cdot 32 \pm 1 \cdot 19 \mathrm{nmol} / \mathrm{ml}$; tryptophan: insulinoma $56 \cdot 2 \pm 2.9 \mathrm{nmol} / \mathrm{ml}$, control $45.0 \pm 4.8 \mathrm{nmol} / \mathrm{ml}$. As shown in Table 2 , the concentration of serotonin in the small intestine of the tumour bearing rats was not significantly elevated relative to control animals but the greater weight of the small intestine resulted in an increased $(p<0.05)$ total serotonin content. Both concentration $(+22 \%$; $\mathrm{p}<0.05)$ and total content $(+19 \% ; \mathrm{p}<0.05)$ of serotonin were raised in the colons of the tumour rats but concentration and content of serotonin in the caeca were not significantly different in the two groups.

\section{Discussion}

Using a radioenzymatic assay, high concentrations of serotonin $(26 \pm 9 \mathrm{nmol} / \mathrm{g})$ have been measured in extracts of the pancreatic islets of the golden hamster ${ }^{13}$ and electron microscopic autoradiography has demonstrated possible costorage of serotonin and insulin in the B cell of the mouse pancreas. ${ }^{14}$ In view of the high concentration of insulin in extracts of the transplantable insulinomas, ${ }^{34}$ the relatively low concentration of serotonin $(2 \cdot 4 \pm 0.8 \mathrm{nmol} / \mathrm{l})$ was unexpected. The 22-fold higher concentration of tryptophan, together with the absence of 5-hydroxytryptophan and 5-hydroxyindole acetic acid, suggests that the tumour tissue may be deficient in the activity of tryptophan hydroxylase (EC 1.4.16.4). The higher concentrations of circulating serotonin in the insulinoma bearing rats, however, is consistent with the 
Table 2 Effect of a transplantable insulinoma upon concentrations and content of serotonin in the rat intestine.

\begin{tabular}{lllll}
\hline & $\begin{array}{l}\text { nmol/g } \\
\text { Insulinoma }\end{array}$ & Control & $\begin{array}{c}\text { nmol/organ } \\
\text { Insulinoma }\end{array}$ & Control \\
\hline Small intestine & $22 \cdot 3 \pm 1 \cdot 4$ & $21 \cdot 2 \pm 2 \cdot 0$ & $192 \cdot 7 \pm 43 \cdot 4^{*}$ & $136 \cdot 3 \pm 12 \cdot 3$ \\
Colon & $30 \cdot 3 \pm 3 \cdot 0^{*}$ & $24 \cdot 8 \pm 3 \cdot 8$ & $56 \cdot 1 \pm 11 \cdot 0^{*}$ & $41 \cdot 3 \pm 9 \cdot 0$ \\
Caecum & $41 \cdot 4 \pm 5 \cdot 9$ & $41 \cdot 8 \pm 1 \cdot 8$ & $47 \cdot 1 \pm 6 \cdot 3$ & $41 \cdot 9 \pm 6 \cdot 8$ \\
\hline
\end{tabular}

Results are expressed as mean \pm SD. ${ }^{*} \mathrm{p}<0.05 v$ control

alternative explanation that the tumours can synthesise but not store serotonin.

As found in an earlier study, ${ }^{4}$ growth of the tumours resulted in a selective increase in the weight of the small intestine. In contrast to the previously reported $^{4}$ rise $(47 \% ; p<0.01)$ in the tissue concentration of enteroglucagon, the levels of serotonin in the small intestine were not significantly changed. The increased weight of the organ did, however, lead to an increase in total serotonin content. This result supports the view that the increase in enteroglucagon concentration is directly linked to growth of the intestine rather than a non-specific consequence of increased luminal stimulation by malabsorbed nutrients. As the EC cell represents the most abundant enteroendocrine cell type, a non-specific effect of increased passage of food through the gut would be expected to manifest itself in a comparable increase in serotonin concentration. The assertion that enteroglucagon itself exercises a trophic effect upon the mucosa is, at the present time, premature. Sequence analyses of cDNAs encoding preproglucagons from several species ${ }^{15}$ have shown that the prohormone contains the sequence of two glucagon like peptides, termed GLP-1 and GLP-2, in addition to enteroglucagon. Preliminary evidence ${ }^{16}$ indicates that, in the mammalian intestine, proglucagon is processed to enteroglucagon (residues 1-69), GLP-1 (residues 72108) and GLP-2 (residues 126-159). An increase in enteroglucagon concentration, therefore, may be associated with an equivalent rise in GLP-1 and GLP2 concentrations. The availability of synthetic GLP-1 and GLP-2 will permit an investigation of the effects of these peptides on the mammalian enterocyte.

An increase in concentration and content of serotonin in the colons of the insulinoma bearing rats was not reflected in a comparable rise in the caeca. Serotonin affects water and elecytrolyte transport in the rat colon by stimulating active chloride secretion and inhibiting neutral sodium chloride absorption. ${ }^{17}$ Diarrhoea is a common feature of the tumour bearing animals that is not observed in the controls and this symptom may thus be directly related to the observed increase in circulating and colonic serotonin concentrations.
The work was supported by the Stiftung Volkswagenwerk and the Cancer Research Campaign, UK (SP 1630).

\section{References}

1 Chick WL, Warren S, Chute RN, et al. A transplantable insulinoma in the rat. Proc Natl Acad Sci USA 1977; 74: 628-32.

2 Flatt PR, Tan K, Bailey CJ, et al. Plasma glucose and insulin concentrations after implantation and surgical resection of transplantable rat insulinoma. Biochem Soc Trans $1982 ; 10$ : $273-4$.

3 O'Hare MMT, Shaw C, Swanston-Flatt SK, et al. Influence of a transplantable insulinoma on the pancreatic status of insulin and pancreatic polypeptide in the rat. Diabetologia 1985; 28: 355-8.

4 Conlon JM, Deacon CF, Bailey CJ, Flatt PR. Effects of a transplantable insulinoma upon regulatory peptide concentrations in the gastrointestinal tract of the rat. Diabetologia 1986; 29: 334-8.

5 Barrowman JA. The trophic action of gastro-intestinal hormones. Digestion 1975; 12: 92-104.

6 Bloom SR, Polak JM. Trophic influence in the gut. In: Bloom SR, Polak JM, eds. Systematic role of regulatory peptides. Stuttgart, New York: Schattauer, 1982: 2217.

7 Gleeson MH, Bloom SR, Polak JM, Henry K, Dowling RH. Endocrine tumour in kidney affecting small bowel structure, motility, and absorptive function. Gut 1971; 12: 773-82.

8 Ferri GL, Adrian TE, Ghatei MA, et al. Tissue localization and relative distribution of regulatory peptides in separated layers from the human bowel. Gastroenterology 1983; 84: 777-86.

9 Furness JB, Costa M. Identification of gastrointestinal neurotransmitters. In: Bertaccius G, ed. Handbook of experimental pharmacology. Berlin: Springer-Verlag, 1982; 59: 383-460.

10 Forsberg EJ, Miller RJ. Regulation of serotonin release from rabbit intestinal enterochromaffin cells. J Pharmacol Exp Ther 1983; 227: 755-66.

11 Flatmark T, Wahlstrom Jacobsen S, Haavik J. Fluorometric detection of tryptophan, 5-hydroxytryptophan and 5-hydroxytryptamine (serotonin) in high performance liquid chromatography. Anal Biochem 1980; 107: 71-4.

12 Richter G, Stöckmann F, Conlon JM, Creutzfeldt W. Serotonin release into blood following food and pentagastrin: studies in healthy subjects and in patients with 
metastatic carcinoid tumors. Gastroenterology 1986; 91 : 612-18.

13 Bird JL, Wright EE, Feldman JM. Pancreatic islets. A tissue rich in serotonin. Diabetes 1980; 29: 304-8.

14 Ekholm R, Ericson LE, Lundqvist I. Monoamines in the pancreatic islets of the mouse. Subcellular localization by electron microscopic autoradiography. Diabetologia 1971 ; 7 : 339-48.

15 Lopez LC, Li W-H, Frazier ML, Luo C-C, Saunders GF. Evolution of glucagon genes. Mol Biol Evol 1984; 1:
335-44.

16 Holst JJ, Orskov C, Nielsen OV, Knuhtsen S. Differential processing and secretion from the pancreas and intestinal mucosa of GLP-1 and GLP-2 peptide sequences of the glucagon precursor. Diabetes Res Clin Proc 1985; Suppl I: S 248.

17 Zimmermann TW, Binder HJ. Serotonin-induced alteration of colonic electrolyte transport in the rat. Gastroenterology 1984 ; 86: 310-7. 